Kelaniya Journal of Human Resource Management

Volume 11, Number 02 - July 2016

DOI: http://doi.org/10.4038/kjhrm.v11i2.29

\title{
Effects of Quality of Work-Life on Turnover Intention: Evidence from Sewing Machine Operators in Sri Lankan Apparel Industry
}

\author{
D. R. N. S. K. Karunanayake ${ }^{1}$ and S. S. Weligamage ${ }^{2}$ \\ ${ }^{1}$ Department of Management Studies, Sri Lanka International Buddhist Academy \\ ${ }^{2}$ Department of Finance, University of Kelaniya, Sri Lanka \\ Inadeera2004@gmail.com, 2.susima@kln.ac.lk
}

\begin{abstract}
High employee turnover among sewing machine operators (SMOs) is one of the critical problem facing apparel industry in Sri Lanka as it create high cost to the organizations. The purpose of this study was to investigate the effects of Quality of Work Life ( $Q W L)$ on turnover intention among the sewing machine operators in apparel industry in Sri Lanka. This study covered sewing machine operators in Sri Lanka with the sample size of 350 and data were collected through a structured questionnaire. Findings revealed that the majority of the respondents were females and 91\% of the respondents were young. The results also illustrated that there is a relationship between $Q W L$ and turnover intention and the study further indicated that most of the respondent were dissatisfied with their work life and showed their willingness to leave. According to the results of Pearson's Correlation analysis, it was found that QWL were negatively and significantly correlated with turnover intention of SMOs. The study further indicated that there is a strong negative relationship between these two variables. Regression analysis shows that $56 \%$ of the turnover intention among SMO's was explained by QWL. This study concluded that satisfied employees will positively contribute to the organizational goals and assured that quality of work life will not only attract young and new talent but also retain the existing talent.
\end{abstract}

Keywords: Quality of work life, Cost effectiveness, Turnover intention, Sewing Machine Operators, Apparel industry

\section{Introduction}

Apparel industry has become Sri Lanka's largest export industry since 1986 and also it has become the country's largest net foreign exchange earner since 1992 (Dheerasinghe, n.d.). Today it has become one of the major and 
important sector in Sri Lanka as it help to reduce unemployment. There are more than 1060 garment factories in Sri Lanka and it provides more than 330,000 direct employment or its represent 5 per cent of country's total employment. The major problem of the apparel industry is the problems in developing and maintaining the required manpower (Dheerasinghe, n.d.).

High employee turnover among SMOs becomes one of the major issues in the industry and most apparel companies in Sri Lanka are experiencing this high labor turnover among the sewing machine operators. It has become a critical issue as it creates high cost to the company (Dheerasinghe, n.d.).The high demand for the sewing machine operators within the industry encourage to turnover themselves. It has badly affected to decrease the loyalty of the employees towards the organization. Organization should be more flexible than earlier in order to retain their valued work force by reducing their turnover intention. Hiring skilled and knowledgeable person for a job is very important for the organization in order to take competitive advantages. But retention is the most important thing than hiring. Today, the employee turnover is one of the most critical problems facing every organization as it create high cost to the organization. Turnover is a costly problem and further, argued that, the cost related to the employee turnover can be classified as separation cost, replacement cost training cost, and hidden cost (Mathis \& Jackson, 2006). Joshi (2002) has mentioned in her study that $90 \%$ of the garment workers are female, which signifies unprecedented entry of female workers in manufacturing activities.

The companies which are selected for this study maintained records showed the following turnover rates per annum.

Table 1. Annual turnover rates of five selected companies

\begin{tabular}{|l|c|c|c|c|c|}
\hline & $\begin{array}{c}\text { Company } \\
\mathbf{1}\end{array}$ & $\begin{array}{c}\text { Company } \\
\mathbf{2}\end{array}$ & $\begin{array}{c}\text { Company } \\
\mathbf{3}\end{array}$ & $\begin{array}{c}\text { Company } \\
\mathbf{4}\end{array}$ & $\begin{array}{c}\text { Company } \\
\mathbf{5}\end{array}$ \\
\hline 2012 & $62 \%$ & $51 \%$ & $61 \%$ & $55 \%$ & $38 \%$ \\
\hline 2013 & $65 \%$ & $60 \%$ & $49 \%$ & $52 \%$ & $41 \%$ \\
\hline 2014 & $64 \%$ & $58 \%$ & $53 \%$ & $57 \%$ & $47 \%$ \\
\hline
\end{tabular}

Source: Company Records 
Researchers have identified in general, factors affecting to this problem such as poor management, lack of recognition, poor working conditions, dissatisfaction with remuneration, lack of career development opportunities, inability to handle various types of stress etc. (Liyanage \& Galhena, 2014). Creating Quality of work life among the employees is the best way reduce the turnover intention among them and ultimately it helps to retain the talented employees. This study explored the effects of quality of work life on turnover intention among sewing machine operators in the apparel industry in Sri Lanka with following objectives;

- To identify the relationship between turnover intention and demographic variables of gender, age, working experience and level of education.

- To determine effects of Quality of work life on turnover intention.

- To analyze what are the most influential QWL dimensions which could affect turnover intention of sewing machine operators.

\section{Literature Review}

QWL is a major issue for employees, and how organizations deal with this issue is both of academic and practical significance. A higher quality of life at work will undoubtedly be determined by elements relating to better or worse relationships, and trust and commitment with bosses and/or subordinates (Requena, 2003). Brief (1998) highlighted, If a person's work is interesting, her pay is fair, her promotional opportunities are good, her supervisor is supportive, and her coworkers are friendly, then a situational approach leads one to predict she is satisfied with her job. This announced that, if the pleasures associated with one's job, there is some level of job satisfaction.

Hackman and Oldham (1980) illustrated that the personal needs are satisfied when rewarded from the organization, such as compensation, promotion, recognition, meet their expectation.

According to Danna and Griffin (1999) point of view, quality of work life is not a unitary concept, but has been seen as incorporating a hierarchy of perspectives that not only include work based factors, such as job satisfaction, satisfaction with pay and relationship with work colleagues, but 
also factors that broadly reflect life satisfaction and general feelings of wellbeing. Bhatia and Valecha (1981) through their research paper on 'A Review of research finding on Absenteeism " revealed about the close relationship between absenteeism rates and quality of work life, she further recommended that keen attention should be paid to improve the quality of work life. Employees, who work in organizations where quality of work life exists, will like their organizations and feel that their work fulfills their needs (Bhatia and Valecha, 1981).

Different studies identified dimension of quality of work life differently. Levine (1984) Europe identified, respect from supervisor and trust on employee's capability, change of work, challenge of the work, future development opportunity arising from the current work, self-esteem, scope of impacted work and life beyond work itself, contribution towards society from the work, impact on quality of work life.

According to Mirvis and Lawler (1984), Safe work environment, equitable wages, Equal employment opportunities and opportunities for advancement can be recognized as the dimension of quality of work life. Baba and Jamal (1991) introduced following dimensions, job satisfaction, Job involvement, work role ambiguity, work role conflict, work role overload, job stress, organizational commitment and turn-over intentions. Lau and Bruce (1998) considered Job security, reward systems, training, carrier advancements opportunities, participation in decision making as the dimensions.

Ellis and Pompli (2002) identified, poor working environments, resident aggression, workload, inability to deliver quality of care preferred, balance of work and family, shift work, lack of involvement in decision making, professional isolation, lack of recognition, poor relationships with supervisor/peers, role conflict, lack of opportunity to learn new skills.

The eight dimensions of QWL which were introduced by Walten (1975) such as adequate and fair compensations, safe and healthy working condition, opportunity to use and develop human capacities, opportunity for continued growth and security, social integration in the work organization, constitutionalism in the work organization, work and total life space, social relevance of work life., were chosen to be analyzed within the scope of this study. 
Different authors used different labels to introduce turnover, such as quits, attrition, exits, mobility, migration or succession. According to Morrell (2001), this measurement of turnover is rarely used, since it fails to distinguish between cases where individuals have decided to leave and cases where they had to leave, as well as ignoring the reasons why they leave is important to consider. Morrell (2001) identified three characteristics of turnover, voluntariness, avoid ability, functionality. According to Morrell (2001), the voluntariness, it is considered two types of turnover such as voluntary turnover and involuntary turnover. Turnover intention is not explicit like actual turnover. According to Berndt (1981) intentions are a statement about a specific behavior of interest.

\section{Research Methodology}

\subsection{Population and Sampling Techniques}

The population of the study covers sewing machine operators from the big five apparel companies in Sri Lanka with the sample size of 350 employees. Simple Random sampling method use to select the sample.

\section{Conceptual Framework}

Conceptual frame work created based on literature (Walton's QWL model, 1975) and it included eight dimensions which are used to measure QWL and demographic factors. The eight dimensions of QWL included in the study are adequate and fair compensation, working conditions, opportunity to use and develop Human capacities, opportunity for continue growth and security, social integration in the work organization, constitutionalism in the work organization, work and total life space, social relevance of work life. The dependent variable is turnover intention.

Figure 01 shows the conceptual framework develop for this study based on literature. 


\section{QWL Dimensions}

Adequate and fair compensations

Safe and healthy working condition

Develop human capitals

Social integration

Social relevance

Total life space

Growth and Security

Constitutionalism

\begin{tabular}{|l|}
\hline \multicolumn{1}{|c|}{ Demographic Variables } \\
\hline Gender \\
Age \\
Level of Education \\
Working experience
\end{tabular}

Turnover Intention

Figure 1: Conceptual Framework

\subsection{Hypotheses Development}

H1: There is a negative relationship between QWL and turnover intention.

H2: There is a negative relationship between QWL dimensions and turnover intention.

H3: There is a significant relationship between turnover intention and demographic variables of age, working experience and the level of education.

\section{Data Collection and Data Analysis}

The questionnaire is designed to measure the factors influencing turnover intentions where the relationship of the affected variables is analyzed. The demographic variables are measured by using nominal scale and the demographic variables measured are gender, age range, level of education and working experience. Walton quality of work life questionnaire was used to measure the independent variables and five questions to measure the dependent variable. Respondents were asked to indicate their perception on 
QWL and turnover intention. The questions designed with five point Likert scale ranging from highly dissatisfied to highly satisfy to measure the eight dimensions of QWL and respondents will have to designate their levels of satisfaction and dissatisfaction. 33 questions covers this eight dimension.

The collected data entered to the Statistical Package for Social Sciences (SPSS) for data analysis. The descriptive statistics such as frequencies, percentages and graphs are used for the analysis of the research questions while the hypotheses testing were done with Pearson Correlation Coefficient, regression, ANOVA and t-test.

\section{Results and Discussion}

\subsection{Profile of Sample}

The questionnaire distributed among 350 SMO's $(n=350)$. The overall response rate $94 \%(n=332)$. The majority of the respondent were female and it was $88 \%(n=292)$ out of the total sample. Approximately half of the sample $(N=190,57.8 \%)$ was between $16-25$ years and most of the employees studied up to advanced level $(n=173,52.1 \%) .40 \%(n=133)$ of the respondents were in 1year to 3 years in there level of working experience. Table 2 presents the summery of the demographic variables and descriptive analysis of turnover intension. Different in the total of percentage indicates the value of missing data.

Table 2: Demographic Profile of the Sample

\begin{tabular}{|c|c|c|c|}
\hline Variable & $\begin{array}{c}\text { Count } \\
(n=332)\end{array}$ & $\%$ & $\begin{array}{c}\text { Turnover } \\
\text { Intension } \\
\text { ( Mean) }\end{array}$ \\
\hline Gender & $n=325$ & & \\
\hline Female & 288 & 87.7 & 4.05 \\
\hline Male & 37 & 11.4 & 4.01 \\
\hline Age & $n=325$ & & \\
\hline $16-25$ & 192 & 58.1 & 4.11 \\
\hline $26-35$ & 106 & 32.8 & 4.08 \\
\hline $36-45$ & 22 & 6.6 & 3.77 \\
\hline $46-55$ & 5 & 1.5 & 2.72 \\
\hline
\end{tabular}


Kelaniya Journal of Human Resource Management

Volume 11, Number 02 - July 2016

\begin{tabular}{|l|r|r|r|}
\hline Variable & $\begin{array}{c}\text { Count } \\
(\boldsymbol{n = 3 3 2})\end{array}$ & $\%$ & $\begin{array}{c}\text { Turnover } \\
\text { Intension } \\
\text { ( Mean) }\end{array}$ \\
\hline Experience & $n=322$ & & \\
Less than 6 months & 30 & 9.0 & 3.97 \\
6 months - 1year & 89 & 27.1 & 4.06 \\
1 year - 3 years & 137 & 41.9 & 4.02 \\
3 years - 5 years & 45 & 13.9 & 4.10 \\
More than 5 years & 21 & 6.3 & 3.96 \\
\hline Education Level & $n=321$ & & 4.02 \\
Ordinary level & 135 & 41 & 3.97 \\
Advanced level & 167 & 51.2 & 4.72 \\
Graduate & 19 & 5.7 & \\
\hline
\end{tabular}

The mean value on turnover intention of female was 4.05 while male was 4.04. This mean value indicates that both male and female agree to leave form the organization.

Results illustrated that the age group $16-25$ years shows 4.11 mean value which indicated that they agree to leave while the employees in $46-55$ years showed their willingness to stay. Age groups $16-25$ and $26-35$ who represented the $91 \%$ of the total respondents showed their intention to leave the organization. Results indicated that respondent who were in 6 months to 1 year, 1 year to 3 years and 3 years to 5 years which showed 4.06, 4.02, and 4.10 mean values have high intention to leave

Approximately half of the sample (52.3\%) studied up to advanced level and $41.1 \%$ studied up to ordinary level and there were 19 graduates which are $5.9 \%$ of the total respondents. Graduates showed the high turnover intention by indicating 4.72 mean values while other two levels of education indicating 4.02 and 3.97 mean values.

\subsection{Reliability Analysis}

Results illustrated that the questionnaire was reliable as it got 0.928 Cronbach's alpha value which was above the standard value with 42 items. . The study used eight dimensions to measure QWL and 5 questions to measure turnover intention. All the dimensions which used to measure independent variable and dependent variable were reliable and Table 3 indicated the reliability of each variables. 
Kelaniya Journal of Human Resource Management

Volume 11, Number 02 - July 2016

Table 3: Reliability Statistics Dimension wise

\begin{tabular}{llcc}
\hline \multicolumn{1}{c}{ Variable/s } & \multicolumn{1}{c}{ Dimension/s } & $\begin{array}{c}\text { No. of } \\
\text { Items }\end{array}$ & Alpha \\
\hline $\begin{array}{llcl}\text { Independent } \\
\text { Variable } \\
(\mathrm{QWL})\end{array}$ & $\begin{array}{l}\text { Adequate and fair } \\
\text { compensation } \\
\text { Safe and healthy working } \\
\text { condition }\end{array}$ & 6 & 0.960 \\
& $\begin{array}{l}\text { Development of human } \\
\text { capabilities }\end{array}$ & 5 & 0.858 \\
& $\begin{array}{l}\text { Growth and security } \\
\text { Social integration }\end{array}$ & 3 & 0.910 \\
& $\begin{array}{l}\text { Constitutionalism } \\
\text { The total life space }\end{array}$ & 4 & 0.969 \\
& $\begin{array}{l}\text { Social relevance } \\
\text { Turnover Intention }\end{array}$ & 3 & 0.911 \\
Dependent Variable & & 5 & 0.955 \\
& & 5 & 0.810 \\
\end{tabular}

\subsection{Hypotheses Testing}

Findings revealed that the QWL is negatively correlated to turnover intention $(\mathrm{r}=-.749 \mathrm{p}=.000)$. The magnitude of the correlation was much closed to 0.75 and it indicates the strong correlations between those two variables. The above correlation is statistically significant as it less than five percent ( $\mathrm{P}$ $<0.05)$ level of significant. In the case of this correlation the null hypothesis would be rejected and the hypothesis 1 (H1) would be accepted as the P-value is less than 0.05 . This concludes that QWL is significantly negative effect on turn over intention.

The study further discussed the relationship between the two variables by using regression analysis in order to illustrate effects of QWL on turnover intention. Adjusted R Square (adj. R2) is .560, which shows that .560 percent variations in employee turnover intention. Table 4 shows the model summary of the regression analysis.

Table 4: Model Summary

\begin{tabular}{ccccc}
\hline Model & R & R Square & $\begin{array}{c}\text { Adjusted R } \\
\text { Square }\end{array}$ & $\begin{array}{c}\text { Std. Error of the } \\
\text { Estimate }\end{array}$ \\
\hline 1 & $.749^{\mathrm{a}}$ & .561 & .560 & .466 \\
\hline
\end{tabular}


The study accepted $\mathrm{H} 1$ and rejected Ho. It is because of significant level of QWL is 0.000 which less than 0.05 . The result shows that the independent variable QWL is significant effect of employee turnover intention as shown by the values of the t-statistic and the corresponding values.

\section{Table 5: Coefficients}

\begin{tabular}{|c|c|c|c|c|c|}
\hline \multirow[b]{2}{*}{ Model } & \multicolumn{2}{|c|}{$\begin{array}{l}\text { Unstandardized } \\
\text { Coefficients }\end{array}$} & \multirow{2}{*}{$\begin{array}{c}\text { Standardized } \\
\text { Coefficients } \\
\text { Beta }\end{array}$} & \multirow[b]{2}{*}{$\mathrm{t}$} & \multirow[b]{2}{*}{ Sig. } \\
\hline & B & Std. Error & & & \\
\hline \multirow{2}{*}{$\begin{array}{l}\text { (Constant) } \\
\text { Quality of } \\
\text { Work Life }\end{array}$} & 5.719 & .090 & & 63.741 & .000 \\
\hline & -.771 & .039 & -.749 & -19.557 & .000 \\
\hline
\end{tabular}

a. Dependent Variable: Turnover Intention

\subsection{QWL Dimensions and Turnover Intention}

The study further illustrates that the relationship between each of the QWL dimensions and turnover intention. $\mathrm{H} 2$ was accepted as the results indicated that there was a negative relationship between QWL dimensions and the turnover intention. Results further revealed that the Safe and healthy working condition dimension shows the higher strong negative correlation $(r=-.739)$ than the other seven dimensions. Constitutionalism shows the least correlation $(\mathrm{r}=-.326)$ towards the turnover intention. All the eight dimensions statistically significant at less than five percent $(\mathrm{P}<0.05)$ level of significant and showed negative relationship towards turnover intention. (See table 6).

Table 6: Correlation between QWL dimensions and turnover intention

\begin{tabular}{lc}
\hline QWL Dimensions & Turnover Intention \\
\hline Adequate and fair compensation & $-.599^{* *}$ \\
Safe and healthy working condition & $-.739^{* *}$ \\
Development of human capabilities & $-.693^{* *}$ \\
Growth and security & $-.590^{* *}$ \\
Social integration & $-.655^{* *}$ \\
Constitutionalism & $-.326^{* *}$ \\
The total life space & $-.636^{* *}$ \\
Social relevance & $-.631^{* *}$ \\
\hline$* *$ Correlation is significant at the 0.01 level (2-tailed). &
\end{tabular}


Regression coefficient results showed there were four (safe and healthy working condition, adequate and fair compensation, development of human capabilities, and total life space) significant dimensions $(\mathrm{P}<0.05)$. Results further revealed that largest beta value in this case was -.489 which was for safe and healthy working condition. Results revealed that adequate and fair compensation (-.393), development of human capabilities (-.227) and total life space (-.239) also best predictors for determining turnover intention. This means that the safe and healthy working condition showed the strongest contribution to explain turnover intention.

Even though bivariate correlation between turnover intention and QWL dimensions of growth and security, social integration, constitutionalism and social relevance were statistically different from zero, those dimension did not significantly contributed to explain turnover intention. Table 7 showed the regression coefficient among QWL dimensions and turnover intention.

Table 7: Regression coefficient of QWL dimensions and turnover intention

\begin{tabular}{|c|c|c|c|c|c|c|}
\hline & \multirow[b]{2}{*}{ Model } & \multicolumn{2}{|c|}{$\begin{array}{c}\text { Unstandardized } \\
\text { Coefficients }\end{array}$} & \multirow{2}{*}{$\begin{array}{c}\begin{array}{c}\text { Standardized } \\
\text { Coefficients }\end{array} \\
\text { Beta }\end{array}$} & \multirow[b]{2}{*}{$\mathrm{t}$} & \multirow[b]{2}{*}{ Sig. } \\
\hline & & B & Std. Error & & & \\
\hline \multirow[t]{9}{*}{1} & (Constant) & 5.930 & .116 & & 50.997 & .000 \\
\hline & $\begin{array}{l}\text { Adequate and fair } \\
\text { compensation }\end{array}$ & -.279 & .159 & -.393 & -1.760 & .049 \\
\hline & $\begin{array}{l}\text { Safe and healthy } \\
\text { working condition }\end{array}$ & -.415 & .062 & -.489 & -6.727 & .000 \\
\hline & $\begin{array}{l}\text { Development of } \\
\text { human capabilities }\end{array}$ & -.200 & .069 & -.227 & -2.892 & .004 \\
\hline & $\begin{array}{l}\text { Growth and } \\
\text { security }\end{array}$ & .186 & .155 & .267 & 1.197 & .232 \\
\hline & Social integration & -.054 & .066 & -.067 & -.822 & .412 \\
\hline & Constitutionalism & -.014 & .032 & -.019 & -.441 & .660 \\
\hline & The total life space & -.233 & .057 & -.239 & -1.586 & .05 \\
\hline & Social relevance & -.037 & .064 & -.038 & -.578 & .564 \\
\hline
\end{tabular}

a. Dependent Variable: Turnover Intention 


\subsection{Demographic Variables and Turnover Intention}

This study observed that there is a significant relationship between education level of the employee and age towards the turnover intention and there is no significant relationship between gender, experience of the employee and turnover intention. One- way ANOVA test used to analyze relationship between demographics variables of educational level, age, working experience, gender and turnover intention.

Findings revealed that mean value of turnover intention of three education types is significantly different. The study used the post hoc tests in order to find which conditions was significantly difference. Tukey HSD test showed that there is a significant difference between Graduate and ordinary level $\mathrm{P}=$ $.000(<0.05)$, and graduate and the advanced level significantly difference $\mathrm{P}=$ $.000(<0.05)$.

Tukey HSD test shows that there is a significant difference between 46- 55 and $16-25$ age groups $\mathrm{P}=.000(<0.05), 45-55$ and $26-35$ age groups $\mathrm{P}=$ $.000(<0.05)$ and $46-55$ and $36-45$ age groups $\mathrm{P}=.006(<0.05)$. There no significant difference between $16-25$ and $26-35$ age groups, $16-25$ and 36 -45 age groups and 26-35 and $36-45$ age groups. There was no significant difference between the means of the two gender groups on turnover intention.

\section{Conclusion}

The purpose of this study was to improve the retention rate of skilled and knowledgeable SMOs as they create high productivity to the organization. Data proved that there was a high employee turnover among sewing machine operators in Sri Lanka. The study followed those eight dimensions which included adequate and fair compensation, safe and healthy working condition, opportunity to use and develop human capacities, opportunity for career growth, social integration in the work force, constitutionalism in the work organization, Work and quality of life and social relevance of work to measure the QWL of SMOs.

Findings of the study illustrated that the QWL negatively affect towards the turnover intention among SMOs. Study further revealed that safety and healthy working condition has strong negative relationship with their 
intention to leave. Demographic variables of education level and age of the employee showed a significant relationship towards the turnover intention by indicating that young and those who were had high education level showed their dissatisfaction on QWL and high intention to leave from the current job. A happy and healthy employee will make good decision and positively contribute to the organizational goal. An assured quality of work life contributes not only in attracting young and new talent but also retain the existing talent. Results of this study revealed that there is a meaningful relationship between adequate and fair compensation. Organizations should implement the fair distribution of wages among the employee and company should pay for the efficiency. Safe and healthy working condition encourage employee to perform well and continue their career with the same organization. Organization should ensure safe and healthy environment while establishing reasonable working hours and working conditions with minimum of physical risk. The next most important factor which organization should consider is to development of human capabilities among the SMOs. This study indicated that nearly $91 \%$ out of total respondents were young who were with various skills and highly appreciate their independency. Organizations could encourage them to decision making and take advantages from their various skills. Opportunities for growth and security highly required by younger generation. Results of the study revealed that there was a high turnover intention among graduates and they were highly dissatisfied with their QWL. Organizations should maintain records of each employee and should provide clear career path with providing necessary training and development while ensuring their job security. Recently most of the educated people not only in apparel industry but also other industries have joined with public service because of job security.

This study showed negative but weak relationship towards constitutionalism. Even though SMOs paid less attention toward constitutionalism than the other QWL dimensions, organization should concentrate on respecting their employees, encourage the freedom of expression and respect their rights will increase the commitment towards the organization which ultimately reduce the intention to leave. Social integration at work creates the better relationship among the boss and the employees, among the employee and employees and it helps reduce the discrimination within the organization. Social integration can be seen in the absence of bias towards race and gender and ethnicity of 
human resources, improvement opportunities in the organizational hierarchy and the socialization. It is important to create the balance between work life and family life. Data analysis illustrated that most of the SMOs dissatisfied their total life space and study revealed that there is some kind of a strong negative relationship towards the turnover intention when it compares to other dimensions. Creating flexible working hours, managing effective leave plans for the employees and especially when recruiting employees should give the priority to people who are in the same area which allows employees to spend more times with their family.

\section{References}

Baba, V.V and Jamal, M (1991) Reutilization of job context and job content as related to employees quality of working life: a study of psychiatric nurses. Journal of organizational behaviour.

Berndt, T. (1981). Effects of Friendship on Prosocial Intentions and Behavior. Child Development, 52 (2), pp. 636-643.

Bhatia, S., \& Valecha, G. (1981). A review of research findings on absenteeism. Indian Journal of Industrial Relations , 17 (2), 279-285.

Brief, A.P. (1998). Attitudes in and Around Organizations. Thousand Oaks, CA: Sage

Danna, K. \& Griffin, R.W. (1999). Health and well-being in the workplace: a review and synthesis of the literature. Journal of Management, 25(3),

Dheerasinghe, R. (n.d.). Garment Industry in Sri Lanka, 33-72.

Dheerasinghe, R. (2009). Garment Industry in Sri Lanka Challenges, Prospects and Strategies. Staff studies, 33(1\&2). 33-72.Doi: 10.4038/ss.v33i1.1246

Ellis, N., \& Pompli, A. (2002). Quality of working life for nurses. Commonwealth Dept of Health and Ageing. Canberra

Gayathiri, R., \& Ramakrishnan, L. (2013). Quality of Work Life - Linkage with Job Satisfaction and Performance, 2(1), 1-8.

Hackman, J.R. and Oldham, G.R. (1980), Work Redesign, Addison-Wesley, Reading, MA.

Joshi, G. (2002). Garment industry in South Asia Rags or riches? Competitiveness, productivity and job quality in the post-MFA environment. South Asia Multi disciplinary Advisory Team. 
Kelaniya Journal of Human Resource Management

Volume 11, Number 02 - July 2016

Lau, R. S. M., \& May, B. E. (1998). A win-win paradigm for quality of work life and business performance ,Human Resource Development Quarterly. 9 (3), 211-226

Levine, M., Taylor, J., \& Davis, L. (1984). Defining quality of work life. Human Relations. 37, 81-104.

Liyanage, D., \& Galhena, B. (2014). Determinants of Turnover Intention of Sewing Machine Operators: Case from leading Apparel Company. Kelaniya Journal of Management, 1(2). doi:10.4038/kjm.v1i2.6535

Mathis, R.L., \& Jackson, J.H. (2006).Human Resource Management (11thed.).Omaha

Mirvis,P. \& Lawler,E.(1984). Accounting for the quality of work life. Journal of Occupational Behaviour, 5,197-212.

Morrell R 2001. Corporal Punishment and Masculinity in South African Schools. Men and Masculinities, 4:2, in press.

Requena, F. (2003). Social capital, satisfaction and quality of life in the workplace. Social Indicators Research, 61, 331-360.

Walton, R.E. Improving the QWL, Harvard Business Review, 19 (12), May-June, 1980, 11-24.

Walton, R. E. (1975), Criteria for Quality of Working Life, in Davis, L.E. \& Cherns, A.B. (eds.), The quality of working life, New York: The Free Press, pp. 99-104. 